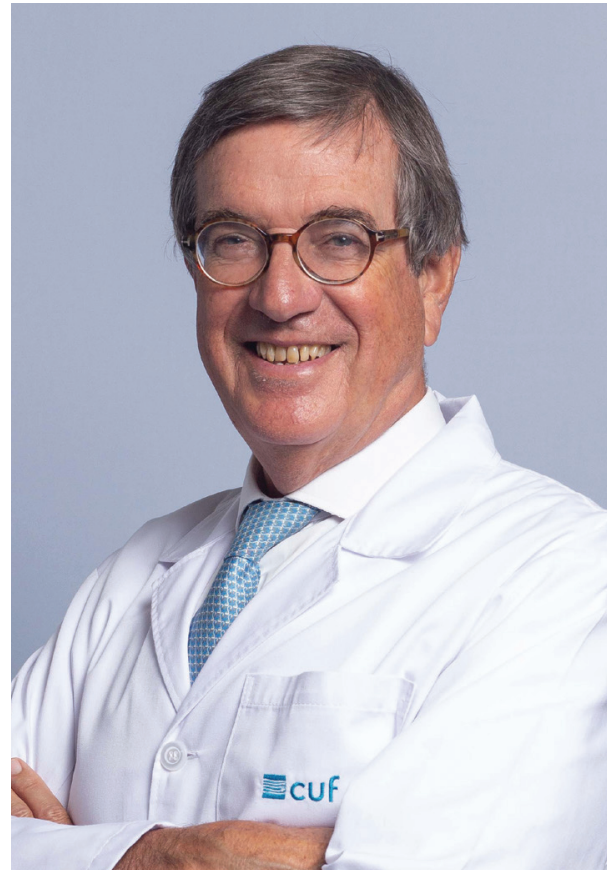

\title{
75 Anos Hospital CUF e COVID-19
}

\section{Years CUF Hospital and COVID-19}

João Paço ${ }^{1}$

Sim, é verdade o Hospital CUF fez 75 anos no passado dia 10 de junho. Nesse dia, no ano de 1945, o Presidente da República General Carmona deslocou-se ao Hospital pelas 12 horas acompanhado pelo ministro da Marinha, o Almirante Américo Tomás, e outras altas individualidades para visitar aquilo que era um hospital inovador construído para os funcionários e trabalhadores da CUF, para os acidentes de trabalho e igualmente para os particulares. Presente estava o Senhor D. Manuel de Mello, Administrador Geral do grupo CUF, pois o Senhor Alfredo da Silva já havia falecido. O hospital dispunha de 20 médicos, 60 especialistas, 100 camas, 12 enfermarias e 24 quartos particulares. O seu corpo clínico era excelente e por lá passaram os melhores clínicos e professores da faculdade de medicina da época. Em 1948 nasce a Gazeta Médica Portuguesa, revista da qual fazem parte um Conselho Científico de excelência com nomes como Celestino da Costa, Almeida Lima, Carlos Larroudé, Carneiro de Moura, Diogo Furtado, Fernando da Fonseca, Jorge Horta, Pulido Valente, entre muitos outros e que constituíam a elite médica da altura. Esta revista, pela sua qualidade e periodicidade, esteve indexada, interrompendo a sua publicação em 1956. É esta revista que ressurgiu e renasceu, sendo hoje a revista da CUF e da José de Mello Saúde.

Setenta e cinco anos depois, já no fim de uma longa carreira sempre a crescer e nos dias de hoje fazendo parte de uma rede de hospitais e clínicas - CUF sobre a égide da José de Mello Saúde, tivemos de enfrentar a COVID-19. Neste período conturbado que vivemos com a pandemia, a CUF disse "presente" e os Hospitais CUF Infante Santo e CUF Porto estiveram destinados a receber doentes COVID-19 ajudando o país no esforço de combater esta pandemia. Ambos os hospitais tiveram de se adaptar e sob o comando dos Programas de Prevenção e Controlo de Infeções e de Resistência a Antimicrobianos (PPCIRA) criar circuitos, dividir espaços, dividir elevadores, adaptar blocos operatórios, aconselhando equipamentos de proteção individual (EPIs) tudo fazendo para receber e tratar o melhor possível todos os doentes. Os hospitais ficaram diferentes, cheios de fitas adesivas vermelhas, amarelas e verdes indicando os percursos e caminhos seguros. Os Serviços de Observação (SOs), os Atendimentos Permanentes e o Internamento da Infante Santo tiveram um reforço no caso dos médicos das CUF Almada, Sintra e Cascais de forma a poderem ajudar as equipas 
submetidas a intenso trabalho, pressão e stress emocional. As Unidades de Cuidados Intensivos Polivalentes (UCIPs) receberam muitos doentes tratando-os e curando-os na sua grande maioria. Uniformizaram-se terapêuticas e métodos de atuação e são os resultados e as experiências únicas vividas ao longo destes 3 meses que estão relatadas neste número especial da Gazeta Médica dedicada à experiência COVID-19.

Uma palavra especial para todos os médicos, enfermeiros, auxiliares, técnicos, pessoal da limpeza, administrativos que durante este período, todos os dias compareceram nos seus postos de trabalho dando o seu melhor e honrando a instituição. Eles são os nossos heróis e para eles vai um abraço e agradecimento muito especial.

Não só para a CUF Infante Santo e CUF Porto, mas também para todas as CUFs, nos vários pontos do País que tiveram de reorganizar-se, tratar e orientar este tipo de doentes, bem como para todos os profissionais do Hospital de Vila Franca de Xira.

Nada disto aconteceu por acaso, desde o primeiro dia foi criado um gabinete de crise ao mais alto nível e que reunindo diariamente, fins-de-semana incluídos, analisava, orientava e decidia as ações a tomar a todo o nível sempre com apoio da Direção Qualidade e Segurança (DQS) e das PPCIRAs.

A organização esteve sempre presente e foi a única forma e foi a maneira de responder a este desafio. Por último, uma vez ultrapassada esta fase, entramos no período da retoma da atividade, voltarmos a fazer tudo aquilo para o qual estamos preparados e que tão bem fazemos... tratar doentes desde 1945 até aos dias de hoje com esperança de um futuro melhor, com novas equipas e 2 hospitais novos a surgirem, CUF Sintra e o tão desejado CUF Tejo. Esperando que este número da Gazeta honre e seja representativo do esforço que foi desenvolvido por todos os profissionais, um muito obrigada e bem hajam. 